\title{
Academic Whatsapp Group: Exploring Students' Experiences in Writing Class
}

\author{
Fatimah Mulya Sari ${ }^{1}$, Shely Nasya Putri ${ }^{2}$ \\ fatimah@teknokrat.ac.id ${ }^{1}$, shelynasyaputri@ teknokrat.ac.id ${ }^{2}$ \\ Universitas Teknokrat Indonesia ${ }^{1,2}$
}

\begin{abstract}
The use of social-networking application such as WhatsApp in learning writing enables students to foster individual learning experiences during the class and after the class. WhatsApp itself has a special feature to create the specific group in order to bound the members and intimate the interaction among lecturer and students relating to the course matters. This current study generally explores the students' perceptions in experiencing WhatsApp Group Chat in learning writing. This qualitative research was conducted in one of universities in Lampung province, Indonesia. The subjects were 28 second year undergraduate students who enrolled writing course. The data used were questionnaire, interview, and observations. The findings present the multitude of views that most students significantly showed positive result to use WhatsApp Group in their writing class. By experiencing WhatsApp Group Chat in their learning writing, the students admitted that it is user-friendly and easy to use because it can intensify the interaction with the other group members during the class and after the class, be effective in submitting the writing assignment by uploading the file in the group, get the lecturer's feedback directly after submitting the writing assignment, and freely ask and share the writing materials. However, some students also revealed that there were some technical problems found when they used the WhatsApp Group Chat such as abundant chats, poor signal, and junks notification. Nevertheless, learning writing through these cross-platform instant messaging might broaden the student's self-learning experiences.
\end{abstract}

Keywords: Students' experience, WhatsApp Group, writing class

\section{Introduction}

Language learner in millennial era plays as an active constructors of knowledge. Learners should be provided with an interactive learning environment where they can actively engage in the teaching and learning process and encourage their interaction with facilitator and others peers, not only during the class but also after the class. As such, language learners should be provided with a user-friendly instructional learning media to help them build their knowledge of language. By implementing instructional learning, the role of language teacher adapts from a facilitator to the traditional formal instructor to support conducive teaching and learning process (Sari \& Wahyudin, 2019).

The rapid growth of technology has shifted personal computers into smartphone since it is user-friendly and more flexible in time and place (Sharples, Taylor, \& Vavoula, 2007; Chen, Hsieh, \& Kinshuk, 2008; Demouy \& Kukulska-Hulme, 2010; Kukulska-Hulme, 2012; Motteram, 2013). Nowadays, millennial students are inseparable by their smartphone. They frequently use it to do many things such as sending message through instant messager, uploading and downloading the pictures and audios through social media, browsing anything through google or others, and reading the flash news or online story such as novel or comic. Therefore, there is a tendency for them to access their smartphone frequently in any occasion during teaching-learning process and outside classroom (Ajid et al, 2018). 
One of social-networking applications that is appropriate and popular among the students as instructional learning mobile media is WhatsApp. WhatsApp application has emerged as one of new potential social networking application that are designed on all current types of devices and operating systems to run both on mobile devices and computers (Bouhnik \& Deshen, 2014; Yebuah \& Ewur, 2014). Through this instant messager application, users are allowed to exchange the information via chat to send multimedia messages such as file, image, video, and audio messages (Chan \& Holosko, 2017; Church $\&$ de Oliveira, 2013). It also has a special feature to create a specific group to enhance communication intensively among the members of group within its boundaries. On the other side, from the implications on pedagogies, the support of WhatsApp in learning process allows the users directly access to numerous of online resources and more focus on the students' creativity, autonomy, and their responsibility on their own learning (Ifenthaler \& Schweinbenz, 2016).

The previous study revealed that WhatsApp is useful and have positive attitudes in fostering learner's autonomous learning experiences, encouraging cooperation, and intensifies motivation to participate actively in academic purposes (Vavoula \& Sharples, 2008; Bere, 2013; Chipunza, 2013; Fattah, 2015; Moreira, et al, 2016). It was also found out that utilizing WhatsApp can motivate students to develop the students' writing skills (Hani, 2014; Maria, 2016). However, the popularity of WhatsApp Group has been exploited to be an educational powerful tool by L2 language practitioners in any areas of language. Therefore, this current study was conducted to investigate the students' perceptions in using WhatsApp Group Chat in the writing class. Through WhatsApp Group, the facilitator or lecturer can design a variety of writing activities.

\section{Method}

This present study was a case study. The subjects were 28 students in the third semester from English Literature study program, Faculty of Arts and Education, Universitas Teknokrat Indonesia that joined writing course in the academic year of 2018/2019. In this course, the students were treated to do and accomplish several writing office letters such as job application letter, CV or resume, memo, letters of payments, personal business letters, electronic mails, and media letters. The lecturer provided the template of letters and shared it to all students through WhatsApp Group created specially for these writing class.

The research data were obtained from questionnaire, interview, and observation. The questionnaires were distributed to all respondents. The questionnaire statements were classified into three sections, namely technical, educational, and instructional. In technical section, there were 12 statements. Educational section consists of 15 statements. Meanwhile, instructional section consists of 6 statements. The total of statements were 33 items, with the scale strongly agree (SA), agree (A), neutral (N), disagree (D), and strongly disagree (SD). To analyze the results of questionnaire, mean score and standard deviation (SD) were used. The interpretations of questionnaire were through the level of strongly disagree (1.00-1.80), disagree (1.81-2.60), neutral/moderate (2.61-3.40), agree (3.41-4.20), dan strongly agree (4.21-5.00).

To strengthen the findings, an open-ended interview was conducted to all participant to explore their respond and prespectives toward the implementation of WhatsApp Group in their writing class. The interview data were transcribed into words to find out the results. Moreover, non-participant observation was simply done to observe some aspects by giving a checklist in the observation sheet. 


\section{Findings}

This section discusses the findings of study by exploring the students' respons in experiencing WhatsApp Group as their learning writing media. Table 1, 2, and 3 describe the means and standard deviations to each item of the questionnaire. The detail results can be seen, as follows:

Table 1. Students' Responses Using Academic WhatsApp Group (Technical Aspect)

\begin{tabular}{l|l|c|c|c}
\hline \multirow{2}{*}{ TECHNICAL ASPECT } & \multicolumn{3}{c}{ Results } \\
\cline { 2 - 5 } Statement 1 & WhatsApp Group Chat is simple to use. & 28 & 4.89 & 0.31 \\
\hline Statement 2 & WhatsApp Group Chat is an easy learning way. & 28 & 4.14 & 0.89 \\
\hline Statement 3 & WhatsApp Group Chat is free of charge. & 28 & 4.25 & 0.75 \\
\hline Statement 4 & $\begin{array}{l}\text { WhatsApp Group Chat is easily available and } \\
\text { down-loadable. }\end{array}$ & 28 & 4.54 & 0.58 \\
\hline Statement 5 & WhatsApp Group Chat is privacy. & 28 & 3.36 & 0.91 \\
\hline Statement 6 & $\begin{array}{l}\text { WhatsApp Group Chat has already been used as } \\
\text { teaching-learning tool. }\end{array}$ & 28 & 4.07 & 0.72 \\
\hline Statement 7 & No smart phone & 28 & 2.18 & 0.9 \\
\hline Statement 8 & WhatsApp Group Chat affects message flooding. & 28 & 3.07 & 0.66 \\
\hline Statement 9 & $\begin{array}{l}\text { WhatsApp Group Chat is time-wasting and time- } \\
\text { consuming. }\end{array}$ & 28 & 2.32 & 0.72 \\
\hline Statement 10 & Group maintenance & 28 & 3.54 & 0.58 \\
\hline Statement 11 & WhatsApp Group Chat makes me eye strain. & 28 & 2.61 & 0.63 \\
\hline Statement 12 & $\begin{array}{l}\text { WhatsApp Group Chat makes me stress. I am } \\
\text { somewhat shy when I reply chatting when I am } \\
\text { being part of the activity. }\end{array}$ & 28 & 2.25 & 0.93 \\
\hline
\end{tabular}

Based on the results of the questionnaire, there were various responses from the students. Each statement has different percentage. Firstly, in the technical section, the means from 12 statements were in different levels. The highest mean was statement 1 (4.89) and the lowest mean was statement 7 (2.18). Statement 1 was indicated as the highest level which meant that most students strongly agreed that WhatsApp Group Chat was simple to use in their writing class. Meanwhile, statement 7 was indicated as the lowest level as most students disagreed that they did not have smart phone so there was no problem for them to install and use WhatsApp in their smart phone.

Table 2. Students' Responses Using Academic WhatsApp Group (Educational Aspect)

\begin{tabular}{l|l|c|c|c}
\hline \multirow{2}{*}{ EDUCATIONAL ASPECT } & \multicolumn{3}{c}{ Results } \\
\cline { 3 - 5 } Statement 1 & $\begin{array}{l}\text { WhatsApp Group Chat is an interesting teaching } \\
\text { platform. }\end{array}$ & 28 & 4.07 & 0.81 \\
\hline Statement 2 & $\begin{array}{l}\text { WhatsApp Group Chat provides a conducive } \\
\text { environment. }\end{array}$ & 28 & 3.64 & 0.73 \\
\hline Statement 3 & Students have sense of belonging to the group. & 28 & 3.64 & 0.68 \\
\hline Statement 4 & $\begin{array}{l}\text { There ia a sufficiency of the time to finish tests } \\
\text { and assignment. }\end{array}$ & 28 & 3.82 & 0.72 \\
\hline
\end{tabular}




\begin{tabular}{l|l|l|l|c}
\hline Statement 5 & $\begin{array}{l}\text { WhatsApp Group Chat is an appropriate platform } \\
\text { English for Foreign Language (EFL) verbal } \\
\text { interaction outside classroom context. }\end{array}$ & 28 & 3.93 & 0.61 \\
\hline Statement 6 & $\begin{array}{l}\text { WhatsApp Group Chat creates interaction } \\
\text { between students. }\end{array}$ & 28 & 4.21 & 0.77 \\
\hline Statement 7 & $\begin{array}{l}\text { WhatsApp Group Chat creates interaction with } \\
\text { facilitator (lecturer). }\end{array}$ & 28 & 4.57 & 0.74 \\
\hline Statement 8 & WhatsApp Group Chat shares learning material. & 28 & 4.18 & 0.5 \\
\hline Statement 9 & The knowledge is clearly constructed and shared. & 28 & 3.96 & 0.61 \\
\hline Statement 10 & $\begin{array}{l}\text { WhatsApp Group Chat is an appropriate platform } \\
\text { for practicing for what you have routinely learnt } \\
\text { in the classroom contexts. }\end{array}$ & 28 & 3.43 & 0.58 \\
\hline Statement 11 & $\begin{array}{l}\text { WhatsApp Group Chat is an appropriate platform } \\
\text { for further practicing of the target language. }\end{array}$ & 28 & 3.57 & 0.57 \\
\hline Statement 12 & $\begin{array}{l}\text { WhatsApp Group Chat is an appropriate platform } \\
\text { for supporting your present language attitudes. }\end{array}$ & 28 & 4.04 & 0.63 \\
\hline Statement 13 & $\begin{array}{l}\text { WhatsApp Group Chat helps to create } \\
\text { opportunity for communication. Whenever I } \\
\text { make mistakes, I can revise them to be a perfect } \\
\text { assignment. }\end{array}$ & 28 & 3.5 & 0.58 \\
\hline Statement 14 & $\begin{array}{l}\text { In WhatsApp Group Chat, doubts immediately } \\
\text { cleared. }\end{array}$ & 28 & 3.54 & 0.58 \\
\hline Statement 15 & The cognitive legibility is provided for us. & 28 & 4.32 & 0.51 \\
\hline
\end{tabular}

In the educational section, statement 7 showed the highest mean with the result 4.57. On the other side, statement 10 was the lowest mean with the result 3.43. Both of the means were indicated as the positive results. Most students strongly agreed that learning writing through WhatsApp Group Chat might create interaction with the lecturer. In addition, most students also agreed that WhatsApp Group Chat was an appropriate platform for practicing for what you have routinely learnt in the classroom contexts, especially in their writing class.

Table 3. Students' Responses Using Academic WhatsApp Group (Instructional Aspect)

\begin{tabular}{l|l|c|c|c}
\hline \multicolumn{2}{l}{ INSTRUCTIONAL ASPECT } & \multicolumn{3}{c}{ Results } \\
\cline { 2 - 5 } Statement 1 & $\begin{array}{l}\text { WhatsApp Group Chat is easy accesibility to } \\
\text { learning material. }\end{array}$ & 28 & 4.32 & 0.77 \\
\hline Statement 2 & $\begin{array}{l}\text { WhatsApp Group Chat provides facilitator's } \\
\text { availability. }\end{array}$ & 28 & 4.04 & 0.64 \\
\hline Statement 3 & Students can learn anytime and anywhere. & 28 & 4.64 & 0.49 \\
\hline Statement 4 & $\begin{array}{l}\text { WhatsApp Group Chat provides secure } \\
\text { environment. }\end{array}$ & 28 & 3.79 & 0.69 \\
\hline Statement 5 & $\begin{array}{l}\text { Learning in WhatsApp Group shows no efforts } \\
\text { by some students. }\end{array}$ & 28 & 3.11 & 0.57 \\
\hline Statement 6 & $\begin{array}{l}\text { Some students share material to impress } \\
\text { facilitator without actually learning about it. }\end{array}$ & 28 & 3.04 & 0.58 \\
\hline
\end{tabular}

Furthermore, in the instructional section, the result showed that statement 3 was the highest mean (4.64). Besides, statement 6 was the lowest mean (3.04). These result showed 
different level. In the statement 3, most students strongly agreed that they can learn anytime and anywhere through WhatsApp Group Chat. In addition, most students were neutral to give response in which they shared material to impress facilitator without actually learning about it.

To strengthen the result of this research, all students were interviewed for several questions related to their experiences using WhatsApp Group in their writing class. From the interview, it was found out that most students discovered several advantages using WhatsApp Grup Chat.

Firstly, there were some students who said that they could access easily the WhatsApp Group Chat anytime. They also could learn the material and do their assignment anywhere and anytime. The following extracts described their positive responses toward this learning media.
EO : We can study and doing assignments anywhere, even though we are no longer at home or in campus.
$R A$ : We could access it anywhere and anytime.
$S A R$ : It's simple to use and we can learn in everywhere or everytime.
$R P \quad: \quad$ It easy to use and accessible for everyone. Also, students can check the materials everytime.
EL : We can learn anywhere and anytime.
SN : Whatsapp group is easy to use and it has fast access so everywhere we can use WhatsApp as media in learning.
ASS : .... we can learn the material everytime and everywhere and also we can use WhatsApp group as our make-up class if the lecturer can't attend the class ....
E $\quad: \quad$.... I can study wherever I want
$M C \quad$ : $\quad$ Students can learn anytime and anywhere if we used whatsApp group.
KS : ........ we can study everytime and everywhere.
$\mathrm{NH} \quad$ : .......... also we can receive the assigment on WA anywhere. I think this is a good I idea for learning via WA group.

Besides, it was admitted that through WhatsApp Group the students might get the teaching materials from the lecturer and the other students. They also could share the material easily. The responses might be seen in the following extracts.

AR : It's easier to share material

$K N \quad$ : We can send and receive messages and material or even assignment easily

$R P$ : It easy to use and accessible for everyone. Also, students can check the materials everytime.

CI : We can see the material that given by lecturer easily

$R F \quad$ : Easy to got material from my friends. Remember the deadline The assignment when $i$ was forgot.

LS : Using WhatsApp group make me easily to ask my lecturer about the material even about next or pass material and it's make more fast answer to know than i must ask the lecturer because sometime they're busy

ASS : .... we don't miss the material

RPA : It's a good way and simple teaching but still focusing on the material.

$K S \quad: \quad . . . .$. we can read the materials easily.

$\mathrm{NH} \quad$ : It makes us easily to share our assignment and easily to get the material ....

The use of WhatsApp also helped the lecturer in sharing the related materials. The lecturer easily uploaded the teaching material in the specific files such as .pdf, .docx., 
pptx., .mp3, and others. It was revealed by most students that their lecturers frequently shared the material related to all subject materials. The following extracts showed that the students received the materials for learning writing.

EO : Yes, is about how to write the letter to other company, how to complaint, about media letter, and so on.

SF : Yes, all the material about Writing in semester 3.

$A R \quad:$ If teacher share the material, sometime I saw it or I wrote the materials in my book

HT : Yes and always share all of the materials.

$R A \quad: \quad Y e s$, she does. She shares the materials of the subject.

SAR : Of course. A lot of materials. Some of them is about letter

$K N \quad$ : Yes, all of the materials are shared by my lecturer

$R P \quad: \quad$ She does. They are mostly the materials that we don't get in the class.

$C L$ : Yes, about invitation letter, anniversary letter, the definition and many more

EL : Yess share it, almost all of the materials that not shared in the class

$R F \quad$ : Yes, every meeting she share the material and if we got confused there have questions and answers sections in whatsapp group

SN : Yes, she does. She shares all of materials such as media letter, CV, invitation,etc.

LS : Yes, she does. That's so many material such as application letter, condolence letter, business inquiry, payment banking, electronic mail, personal business letter, curriculum vitae, memo and etc

ASS : Yes, she does. She always share the material on time. They are invoice message, applicant letter, how to invite our client in other company and many more

RAY : Yes, she does. She shares all of the materials which we will learn every meeting and she uses PowerPoint for the materials.

AR : Almost all.

SK : Yes, my teacher always share all of the materials for this semester

E : All of the material. My lecture always share it in our WAG.

$J D \quad$ : Yes, she does. All of the materials during this semester such as business letter, $C V$, invoice, e mail and others. Related to job requirement letters

$R P A \quad: \quad$ They are media letter, electronic mail, payment letter etc.

$M C \quad$ : All of material, such as invitation letter, congratulation letter, media letter, sympathy letter, thanking letter, apology letter and etc.

$K S \quad$ : Yes, she does. All of materials of this subject in this semester had been shared.

NH : My lecturer always shares and uploads the material. About letter, starting from application letter until business letter.

On the other hand, using WhatsApp Group Chat in the teaching and learning process showed the disadvantage. Some students mentioned that they sometimes misunderstood with the materials uploaded by the lecturer. They needed the face-to-face explanation to the teaching materials. The extracts are as follows:

$H T$ : Sometime hard to understand some materials

CI : It could make me confused a little bit because lecturer will give the explanation through WhatsApp

LS : Little confused when I didn't understanding about the material that lecturer already post and I can't to understand to about the explanation in chat. 
ASS : The disadvantage is we don't really understand about material. It will be better for the students can ask the question directly to lecturer and the lecturer explain it.

$M C$ : When there is explanation of the material in the WhatsApp group is less effective.

KS : The disadvantage of using WhatsApp group chat in our teaching-learning is sometimes there are materials which are tough to be understood if we just read the materials, we need the exact explanation of $i t$.

$\mathrm{NH}$ : Sometimes we didn't really understand about the material and when it has the assigment the student just follow the example without understanding the material and I thnik the student also can cheating to their friends in group

In addition, there were some problems affecting their learning activity in their writing class. The problems were a lot of notification in the phone, message overloaded, and poor internet connection/signal. The extracts showed the students' responses toward the problem faced by them.

AR : Our text easily sinks because too much text is entered. It's too noise if has a lot of texts in group WhatsApp.

SAR : Maybe a lot of notification

$R P$ : Sometimes we got distracted easily when we are on our phone. We also need to have internet connection which sometimes are not there

$R F \quad$ : Noisy and the chat are overflowing

SN : There are many chats come up and it will be trouble if our message is pending in submitting the assignment

SK : The signal can be a problem, or when we forget to check our WhatsApp. And then, pending message which unsent so we will be late in uploading my assignment.

$E \quad:$ If the students or the lecturer's connection bad

$R P A:$ Signal.

$R P$ : Sometimes I need to copy the file from my PC. It is not really troublesome, but I just think that it is easier if I send the file via web.

$H T$ : Sometime we shy to Reply or chat in the WhatsApp group

NW : To many chats

$M C$ : Maybe about the bad connection.

$\mathrm{NH}$ : Maybe the problem is about kuota or about the signal

KS : ..... However, sometimes I was too late to respond it since I was late to open the WhatsApp group.

JD : We often face problem like pending. No quota and others

\section{Discussion}

This current study is designed to explore the students' perspectives to the implementation of WhatsApp Group Chat in writing class. The lecturer ordered students to create a group chat. The findings found out that the students admitted positive feelings and intentions of the use of WhatsApp Group Chat seen from points of technical aspect, educational aspect, and instructional aspect. They overall gained the simplicity and convenience in utilizing WhatsApp Group as their additional learning media. Through WhatsApp Group, the students can get easy and quick transference of links to learning materials. By uploading and sharing its material, it ensures every students get the message to download the files. It is supported by Bouhnik \& Deshen (2014). 
The learning process through WhatsApp Group is furthered by the lecturer's guidances. In daily activity, the students were instructed orderly to compose writing through three steps, namely pre-writing activity, writing activity, and post-writing activity (Richard, 2015). The lecturer completely shared the writing materials in the beginning meeting and asked the students to compose writing assignment based on the material given. Thus, WhatsApp Group is a new and convenient tool for teaching learning activity.

\section{Conclusion}

In the light of the results, it can be concluded that WhatsApp Group Chat might help students in learning writing. Using WhatsApp Group as a writing learning media posed positive experiences for most students' participants. The studentsBeside, there were also some goals achieved from the use of WhatsApp Group such as enhancing comunnication among the member of groups, grooming positive learning atmosphere and a sense of belonging in the writing class, creating a dialogue, and sharing and using a learning materials.

Since most students tend to use their smartphone constantly, it is recommended that the teachers should monitor the process of using this messaging platform to optimalize the advantages of virtual learning. For further research, it is suggested to add sample size with different proficiency levels and choose the other skill courses.

\section{References}

Ajid, L. H., Reni, R., Yunita, D. U., \& Dwi, S. 2018. The Use of WhatsApp in Collaborative Learning to Improve English Teaching and Learning Process. International Journal of Research Studies in Educational Technology, 7(1), 29-35.

Bensalem, E. 2018. The Impact of WhatsApp on EFL Students' Vocabulary Learning. Arab World English Journal (AWEJ), 9(1), 23-38. DOI: https://dx.doi.org/10.24093/awej/vol9no1.2

Bere, A. 2013. Using Mobile Instant Messaging to Leverage Learner Participation and Transform Pedagogy at a South African University of Technology. British Journal of Educational Technology, 44(4), 554-561.

Bouhnik, D. \& Deshen, M. 2014. WhatsApp Goes to School: Mobile Instant Messaging between Teachers and Students. Journal of Information Technology Education: Reserach, 13, 217-231. Retrieved from: http://www.jite.org/documents/Vol13/JITEv13ResearchP217-231Bouhnik0601.pdf

Chan, C. \& Holosko, M. J. 2017. The Utilization of Social media for Youth Outreach Engagement: A Case Study. Qualitative Social Work, 16(5), 680-697. https://doi.org/10.1111/modl.12302

Chen, N. S., Hsieh, Sh.-W., \& Kinshuk, W. 2008. The Effect of Short-Term Memory and Content Representation Type on Mobile Language Learning. Journal of Learning and Technology, 12, 93-113.

Chipunza, P. R. C. 2013. Using Mobile Devices to Leverage Student Access to Collaboratively-generated Resources: A Case of WhatsApp Instant Messaging at a South African University. International Conference on Advanced Information and Communication Technology for Education (ICAICTE 2013). 
Church, K. \& de Oliveira, R. 2013. Whta's Up with WhatsApp?: Comparing Mobile Instant Messaging Behaviors with Traditional SMS. In Proceedings of the $15^{\text {th }}$ International Conference on Human-Computer Interaction with Mobile Devices and Services (pp. 352-361). New York: ACM. https://doi.org/10.1145/2493190.2493225

Demouy, V. \& Kukulska-Halme, A. 2010. On the Spot: Using Mobile Devices for Listening and Speaking Practice on a French Language Programme. Open Learning, 25(3), 217232.

Fattah, S. F. E. S. A. 2015. The Effectiveness of Using WhatsApp Messager as One of Mobile Learning techniques to Develop Students' Writing Skills. Journal of Education and Practice, 6(32), 115-127.

Hani, N. A. B. 2014. The Impact of WhatsApp Group's Utilization of EFL Students' Vocabulary Writing A<e;ioration. International Journal of University Teaching and Faculty Development, 5(2), 73-87.

Ifenthaler, D. \& Schweinbenz, V. 2016. Students' Acceptance of Tablet Pcs in the Classroom. Journal of Research on Technology in Education, 48(4), 306-321. https://doi.org/10.1080/15391523.2016.1215172

Kukulska-Hulme, A. 2012. Language Learning Defined by Time and Place: A Framework for Next Generation Designs. In Diaz-Vera J.E. (ED.). Left to My Own Devices: Learner Autonomy and Mobile Assisted Language Learning. Innovation and Leadership in English Language Teaching, 6, 1-13. UK: Emerald Group Publishing Limited.

Maria, J. 2016. Use of WhatsApp to Enhance Reading and Writing Skills at Undergraduate College Level. Language in India, 16(11).

Moreira, F., Ferreira, M. J., Pereira, C. \& Durão, N. 2016. Collaborative Learning supported bymobile devices: A case study in Portuguese High Education Institutions. In Á. Rocha, A.M. Correia, S. Costanzo \& L.P. Reis (Eds.), New Contributions in Information Systems and Technologies. Springer International Publishing.

Motteram, G. (2013). Introduction: The Benefits of New Technology in Language Learning. In Motteram, G (Ed) Innovations in Learning Technologies for English Language Teaching, British Council, UK.

Richard, J. C. 2015. Key Issues in Language Teaching. UK: Cambridge University Press.

Sari, F. M. \& Wahyudin, A. Y. 2019. Blended-Learning: The Responses from Non-English Students in the Indonesian Tertiary Context. Teknosastik: Jurnal Bahasa dan Sastra, 17(1), 23-28.

. 2019. Undergraduate Students' Perceptions toward Blended Learning through Instagram in English for Business Class. International Journal of Language Education, 3(1), 64-73. DOI: 10.26858/ijole.v1i1.7064

Sharples, M., Taylor, J., \& Vavoula, G. 2007. A Theory for the Mobile Age. In R. Andrews \& C. Haythronwaite (Eds.). The Sage Handbook of E-Learning Research (pp. 221247). London, England: Sage.

Vavoula, G. \& Sharples, M. 2008. Challenges in Evaluating Mobile Informal Learning. In Proceedings of the mLearn 2008 conference (pp. 296-303). UK: Wolverhampton. 
Yeboah, J. \& Ewur, G. 2014. The Impact of WhatsApp Messager Usage on Students Performance in Tertiary Institutions in Ghana. Journal of Education and Practice, 5(6), 157-164.

\section{Acknowlegdement}

The writers would like to express their sincere gratitude to the Ministry of Research, Technology, and Higher Education for granting this research (No: T/140/E3/RA.00/2019, 25 February 2019). 